\title{
SYNTHESIS AND CHARACTERIZATION OF SOME ABUNDANT NANOPARTICLES, THEIR ANTIMICROBIAL AND ENZYME INHIBITION ACTIVITY
}

\author{
SHAMS T. KHAN ${ }^{1 *}$, AJMALUDDIN MALIK ${ }^{2}$, RIZWAN WAHAB ${ }^{1}$, \\ OMAR H. ABD-ElKader ${ }^{1}$, MAQusood AHAMED ${ }^{3}$, JAVEd AhMAD ${ }^{1}$, \\ JAVED MUSARRAT ${ }^{4}$, MAQSOOD A. SIDDIQUI ${ }^{1}$ and \\ ABDUlaZIZ A. Al-KHEDHAIRY ${ }^{1}$ \\ ${ }^{1}$ Zoology Department, College of Science, King Saud University, Riyadh, Saudi Arabia \\ ${ }^{2}$ Biochemistry Department, King Saud University, Riyadh, Saudi Arabia \\ ${ }^{3}$ King Abdullah Institute for Nanotechnology, King Saud University, Riyadh, \\ Saudi Arabia \\ ${ }^{4}$ Department of Agricultural Microbiology, Faculty of Agricultural Sciences, \\ Aligarh Muslim University, Aligarh, India
}

(Received: 3 June 2016; accepted: 27 October 2016)

\begin{abstract}
Although the antimicrobial activity of the engineered nanoparticles (NPs) is well known, the biochemical mechanisms underlying this activity are not clearly understood. Therefore, four NPs with the highest global production, namely $\mathrm{SiO}_{2}$, $\mathrm{TiO}_{2}, \mathrm{ZnO}$, and $\mathrm{Ag}$, were synthesized and characterized. The synthesized $\mathrm{SiO}_{2}, \mathrm{TiO}_{2}$, $\mathrm{ZnO}$, and Ag NPs exhibit an average size of $11.12,13.4,35$, and $50 \mathrm{~nm}$, respectively. The antimicrobial activity of the synthesized NPs against bacteria and fungi were also determined. NPs-mediated inhibition of two very important enzymes, namely urease and DNA polymerase, is also reported. The synthesized NPs especially Ag and ZnO show significant antimicrobial activity against bacteria and fungi including methicillin-resistant Staphylococcus aureus even at low concentration. The DNA polymerase activity was inhibited at a very low concentration range of $2-4 \mu \mathrm{g} / \mathrm{ml}$, whereas the urease activity was inhibited at a high concentration range of $50-100 \mu \mathrm{g} / \mathrm{ml}$. Based on their ability to inhibit the urease and DNA polymerase, NPs can be arranged in the following order: $\mathrm{Ag}>\mathrm{ZnO}>\mathrm{SiO}_{2}>\mathrm{TiO}_{2}$ and $\mathrm{Ag}>\mathrm{SiO}_{2}>\mathrm{ZnO}>\mathrm{TiO}_{2}$, respectively. As the synthesized NPs inhibit bacterial growth and suppress the activity of urease and DNA polymerase, the use of these NPs to control pathogens is proposed.
\end{abstract}

Keywords: nanoparticles, antimicrobial activity, urease, DNA polymerase

*Corresponding author; E-mail: shamsalig75@gmail.com 


\section{Introduction}

Global production of engineered nanomaterials is increasing rapidly with their increasing use in various commercial products. Three nanoparticles (NPs) with the highest global production are $\mathrm{SiO}_{2}, \mathrm{TiO}_{2}$, and $\mathrm{ZnO}$ with an annual production of 5,500, 3,000, and 550 tons/year, respectively $[1,2]$. Owing to the desired biological and physicochemical properties, $\mathrm{TiO}_{2}$ and $\mathrm{ZnO}$ NPs are being already used in a number of commercial products $[3,4]$. It is also suggested that these NPs can be used as an alternative antimicrobial agent as they exhibit excellent antimicrobial activities against a number of pathogens and human oral microbiome [5-8]. Although the antimicrobial activity of these NPs is well known, the mechanisms underlying this activity are not well understood. NPs-mediated inhibition of enzymes and/or biochemical pathways should be studied to understand their biocidal properties.

Urease is one of the important enzymes from human health and environmental health point of view. Urease helps urinary tract infection bacteria to establish themselves in humans, in fact, it is emerging as a general microbial virulence factor [9]. Furthermore, urease-producing bacteria in soils also result in the conversion of urea in the soil to a volatile product ammonia making it unavailable to plants [10]. To the best of our knowledge, there is no report so far on the NPs-mediated inhibition of urease. Another important and vital enzyme is DNA polymerase. Although there are some reports on quantitative inhibition of DNA polymerase in vitro [11], the binding affinity of NPs to DNA molecules and NPs-mediated DNA damage have also been demonstrated earlier [12, 13]; but to our knowledge, there is no report on the qualitative inhibition of DNA polymerase activity.

Therefore, here in this study, we report for the first time NPs-mediated inhibition of urease and DNA polymerase using mutation detection system/ denaturing gradient gel electrophoresis (DGGE). This study also reports the antimicrobial activity of the synthesized NPs against bacteria and fungi including methicillin-resistant Staphylococcus aureus (MRSA).

\section{Materials and Methods}

\section{Synthesis and characterization of NPS}

All the chemicals used for the synthesis of NPs were purchased from SigmaAldrich (Sigma, USA). $\mathrm{SiO}_{2}$ and $\mathrm{ZnO}$ NPs were synthesized using sol-gel methods of Nandanwar [14] and Raja et al. [15], respectively, whereas $\mathrm{TiO}_{2}$ 
NPs were synthesized using the hydrothermal method of Castro et al. [16], and Ag NPs were synthesized as described elsewhere [17].

$\mathrm{SiO}_{2}$ NPs powder was annealed at $300{ }^{\circ} \mathrm{C}$ for $60 \mathrm{~min}$ (Nabertherm, Inc. New Castle, USA) at a rate of $5{ }^{\circ} \mathrm{C} / \mathrm{min}$ before characterization. X-ray diffraction (XRD) patterns of the NPs were obtained using PANalytical X'Pert X-ray diffractometer (Spectris plc, England) equipped with a $\mathrm{Ni}$ filter using $\mathrm{Cu} \mathrm{K} \alpha(\lambda=54,056 \AA)$ radiations, as an X-ray source. Details of size and shapes of NPs were confirmed using scanning electron microscopy (SEM; JSM-6380, JEOL) and transmission electron microscopy (TEM; JEM-2100F, JEOL) analysis. The particle size distribution was determined by dynamic light scattering (DLS) using ZetaSizer-HT (Malvern, UK).

Antimicrobial activity of the synthesized NPs

Microbicidal activity of the synthesized NPs was determined using modified Kirby-Bauer disk diffusion method. Strains of Escherichia coli ATCC 25922, Micrococcus luteus ATCC 10240, MRSA ATCC 43300, and Candida albicans ATCC 10145 were grown to late log phase in sterile Luria broth, Müller-Hinton broth, nutrient broth, and potato dextrose broth, respectively. After inoculation, strains were incubated on a rotary shaker at $150 \mathrm{rpm}$ at their respective optimal growth temperatures. The cultures containing $10^{5}-10^{6}$ cells $/ \mathrm{ml}$ were mixed with soft agar $(0.7 \%$ agar), and the agar plates were seeded with this mixture. Plates were allowed to cool and solidify at room temperature for 10-15 min. Wells with a diameter of $7 \mathrm{~mm}$ were punched into the soft agar layer for testing the antimicrobial activity of nanomaterials. An aliquot of $50 \mu \mathrm{l}$ containing $50 \mu \mathrm{g}$ of the NPs was added to the wells. Plates were incubated overnight at their respective optimal temperature for growth. Following incubation, zones of inhibitions were measured and recorded.

\section{Urease inhibition assay}

Urease assay was performed in 96-well plates as described below. Urease working solution containing 200-400 units/ml was prepared in ice-cold sodium phosphate buffer $\left(20 \mathrm{mM}, \mathrm{pH} 7,25^{\circ} \mathrm{C}\right)$ immediately before use. To $96 \mu$ of urea solution [containing $500 \mathrm{mM}$ urea with $0.05 \%(\mathrm{w} / \mathrm{v})$ bovine serum albumin], test NPs were added to a final concentration of 25,50 , and $100 \mu \mathrm{g} / \mathrm{ml}$. To this reaction mixture, $10 \mu \mathrm{l}$ of phenol red stock solution indicator $(0.12 \mathrm{mg} / \mathrm{ml})$ was added. Finally, to start urease reaction in the presence of NPs, to each well $4 \mu \mathrm{l}$ of urease solution prepared above was added. The reaction mixture was incubated at 
$37^{\circ} \mathrm{C}$ for $5 \mathrm{~min}$ and the color developed was read at $560 \mathrm{~nm}$ using a plate reader (Multiskan Ascent, Labsystems, Finland). The reaction was performed in triplicates, and the change in the activity was calculated by comparing the values obtained at different concentrations of NPs with those obtained without any NPs.

\section{Genomic DNA preparation and PCR amplification}

Genomic DNA from E. coli ATCC 25922 was prepared using QIAamp DNA Mini Kit (Qiagen, Venlo, The Netherlands). DNA was also prepared from a human oral slurry sample using the same kit to be used as positive control for DGGE. The pair of universal primers, $27 \mathrm{f}$ and $1492 \mathrm{r}$, was used to amplify the portion of the 16S rRNA [18] in the presence of $0,0.5,1,2$, and $4 \mu \mathrm{g} / \mathrm{ml}$ of NPs. For DGGE analysis, V3 region of $16 \mathrm{~S}$ rRNA gene was amplified using $341 \mathrm{f}$ with GC clamp and $518 \mathrm{r}$ primers in the presence of NPs $(0,0.5,1,2$, and $4 \mu \mathrm{g} / \mathrm{ml})$. For DGGE analysis, two positive controls were used; one was V3 region from a DNA template of a mixed bacterial population (oral slurry) and the second was V3 region amplified using E. coli genomic DNA treated with methyl methanesulfonate (MMS), a known mutagen [19]. PCR products were analyzed on $1 \%$ agarose and on DGGE gels as detailed below.

$D G G E$, electrophoresis, and analysis of the polymerase chain reaction (PCR) products

DGGE analysis of the V3-variable region of 16S rRNA gene was performed using Bio-Rad D-code system (Bio-Rad, CA, USA). PCR products ( 200 bp) were resolved on $8 \%(\mathrm{w} / \mathrm{v})$ polyacrylamide gels containing a gradient of $35 \%-70 \%$ denaturants. Gels were prepared according to the manufacturer's instructions, and DGGE was performed for $2 \mathrm{~h}$ at $200 \mathrm{~V}$. Gels were stained with ethidium bromide, visualized, and recorded using Bio-Rad Gel Doc system (Bio-Rad, CA, USA). Intensities of the bands in the gels were measured using Gel-Quant software (Multiplexed biotechnologies, Inc., IN, USA).

\section{Results}

Synthesis and characterization of NPS

Typical TEM images and XRD analysis of the synthesized NPs are shown in Figure 1. Based on the TEM and XRD analysis, the size of the synthesized NPs are 

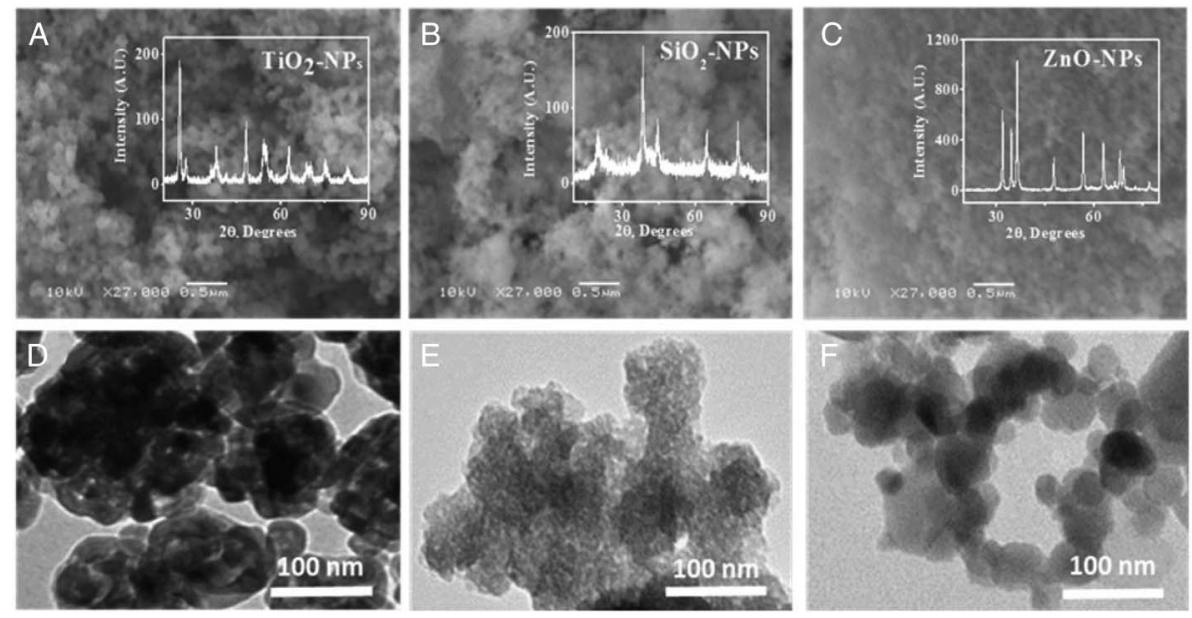

Figure 1. SEM and TEM photographs of NPs. A, B, and C show the SEM images, and D, E, and F show the TEM images of $\mathrm{TiO}_{2}, \mathrm{SiO}_{2}$, and $\mathrm{ZnO} \mathrm{NPs}$, respectively. Inset: XRD pattern

Table I. Sizes of NPs measured using TEM, XRD, and DLS analysis

\begin{tabular}{|c|c|c|c|c|c|}
\hline \multirow{3}{*}{$\begin{array}{l}\text { Nanoparticles } \\
\text { Conc. }(\mu \mathrm{g} / \mathrm{ml})\end{array}$} & \multicolumn{5}{|c|}{ Size $(\mathrm{nm})$} \\
\hline & \multirow[b]{2}{*}{ TEM } & \multirow[b]{2}{*}{ XRD } & \multicolumn{3}{|c|}{ Hydrodynamic size } \\
\hline & & & 50 & 100 & 200 \\
\hline $\mathrm{Ag}$ & 50 & 42 & 142 & 186 & 199 \\
\hline $\mathrm{SiO}_{2}$ & 11.12 & 11.12 & 326 & 332 & 397 \\
\hline $\mathrm{TiO}_{2}$ & 13.4 & 13 & 1,272 & 1,314 & 1,802 \\
\hline $\mathrm{ZnO}$ & 35 & 35 & 176 & 191 & 292 \\
\hline
\end{tabular}

summarized in Table I. The size of $\mathrm{Ag}, \mathrm{SiO}_{2}, \mathrm{TiO}_{2}$, and $\mathrm{ZnO}$ were 50, 11.12, 13.4, and $35 \mathrm{~nm}$, respectively. In XRD analysis, the peaks of $\mathrm{TiO}_{2}$ nanopowder are identified to correspond to (101), (004), (200), (105), and (211) crystal planes. Hence, all the diffraction peaks are well defined and can be perfectly assigned to anatase $\mathrm{TiO}_{2}$ (JCPDS-21-1272). Similarly, the peaks of $\mathrm{ZnO}$ NPs at $2 \theta=32.06^{\circ}$, $34.66^{\circ}, 36.54^{\circ}, 47.82^{\circ}, 56.89^{\circ}$, and $63.16^{\circ}$ were assigned to (100), (002), (101), (102), (110), and (103) crystal planes, suggesting a polycrystalline wurtzite structure (Zincite, JCPDS 5-0664). XRD pattern of $\mathrm{SiO}_{2}$ with peaks at 19.90 (210), 38.28 (213), 44.62 (332), 64.68 (533), and 77.64 (822) closely matched with the JCPDS files no. 45-0131 with lattice constants of silicon dioxide $(a=13.60 \AA$ and $c=8.227 \AA$; Figure 1C). As discussed above, Ag NPs used 
in this study as positive control were synthesized and characterized in our previous study [17]. The size of NPs determined by XRD analysis was in good agreement with TEM observations (Table I). Hydrodynamic sizes of NPs as determined by DLS analysis can be arranged in the following order: $\mathrm{TiO}_{2}>\mathrm{SiO}_{2}>\mathrm{ZnO}>\mathrm{Ag}$ (Table I). It is interesting to note that $\mathrm{TiO}_{2} \mathrm{NPs}$ despite having a smaller average size of $13.4 \mathrm{~nm}$ only exhibit the largest hydrodynamic size.

Antimicrobial activity of the synthesized NPS

The microbicidal activity of the synthesized NPs in terms of zone of inhibition is shown in Table II. It is important to note that the synthesized NPs especially $\mathrm{Ag}$ and $\mathrm{ZnO}$ NPs show antimicrobial activity at a very low concentration of $50 \mu \mathrm{g} / \mathrm{well}$. Ag and $\mathrm{ZnO}$ NPs show antimicrobial activity against all the test organisms including Gram-positive (M. luteus and MRSA) and Gramnegative (E. coli) bacteria and fungi (C. albicans) as detailed in Table II, whereas $\mathrm{SiO}_{2}$ NPs exhibit moderate antimicrobial activity against only Grampositive bacteria (M. luteus and MRSA). $\mathrm{TiO}_{2} \mathrm{NPs}$ show very mild to negligible antimicrobial activity against all the test organisms with an almost negligible zone of inhibition of $8 \mathrm{~mm}$. Therefore, the NPs can be arranged in the following order based on their antimicrobial activity: $\mathrm{Ag}>\mathrm{ZnO}>\mathrm{SiO}_{2}>\mathrm{TiO}_{2}$.

Inhibition of urease by NPS

Inhibition of urease activity with different NPs is shown in Figure 2. Although all the NPs inhibit urease activity, the significant inhibition was observed with $\mathrm{Ag}$ and $\mathrm{SiO}_{2}$ with a decrease of $21 \%$ and $54 \%$ compared with control at the highest concentration of NPs tested $(100 \mu \mathrm{g} / \mathrm{ml})$, whereas $\mathrm{ZnO}$ and $\mathrm{TiO}_{2}$ NPs decreased the activity of urease by $12 \%$ and $8 \%$, respectively, at the same concentration. Hence, the NPs can be arranged in the following order based on their ability to inhibit urease activity: $\mathrm{Ag}>\mathrm{SiO}_{2}>\mathrm{ZnO}>\mathrm{TiO}_{2}$.

Table II. Antimicrobial activity of the synthesized NPs against bacteria and fungi

\begin{tabular}{lcccc}
\hline \multicolumn{5}{c}{ Zone of inhibition $(\mathrm{mm})^{\mathrm{a}}$} \\
\hline Nanoparticles $(50 \mu \mathrm{g} / \mathrm{ml})$ & M. luteus & MRSA & E. coli & C. albicans \\
\hline $\mathrm{SiO}_{2}$ & 9 & 9 & 8 & 9 \\
$\mathrm{TiO}_{2}$ & 8 & 8 & 8 & 8 \\
$\mathrm{ZnO}$ & 12 & 10 & 9 & 10 \\
$\mathrm{Ag}$ & 16 & 10 & 10 & 14 \\
\hline
\end{tabular}

${ }^{\mathrm{a}}$ The diameter of the well is $7 \mathrm{~mm}$. 


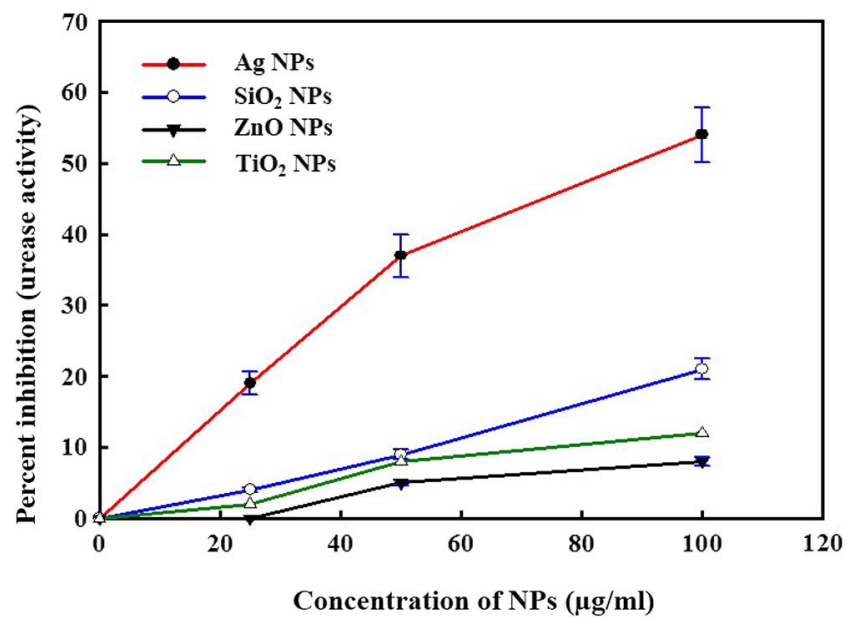

Figure 2. Inhibition of urease activity with various concentrations of NPs. Percent inhibition was calculated by comparing the values obtained for control with the treated samples

Inhibition of $P C R$ reaction by NPS

Inhibition of PCR reaction by the tested NPs as observed on 1\% agarose gel is shown in Figure $3 \mathrm{~A}-3 \mathrm{E}$. The measurement of band intensities using Gel-Quant software shows an inhibition of $1.2 \%, 2 \%, 3.6 \%$, and $7.1 \%$ with 0.5 , 1,2 , and $4 \mu \mathrm{g} / \mathrm{ml}$ of $\mathrm{TiO}_{2}$, respectively (Figure $3 \mathrm{~A}$ ), whereas, an inhibition of $2.8 \%, 4.8 \%, 14.5 \%$, and $23.8 \%$ was observed with $0.5,1,2$, and $4 \mu \mathrm{g} / \mathrm{ml}$ of $\mathrm{SiO}_{2}$, respectively (Figure 3B). Inhibition values observed with $\mathrm{ZnO}$ NPs were comparable to that of $\mathrm{SiO}_{2}$ NPs, as ZnO NPs inhibited the PCR by $2.5 \%$, $4.2 \%, 12.6 \%$, and $26 \%$ with $0.5,1,2$, and $4 \mu \mathrm{g} / \mathrm{ml}$ of NPs, respectively (Figure 3C). The highest inhibition of PCR reaction was observed with $\mathrm{Ag}$ NPs corresponding to $2.7 \%, 9 \%, 17.7 \%$, and $33.1 \%$ with $0.5,1,2$, and $4 \mu \mathrm{g} / \mathrm{ml}$ of Ag NPs, respectively (Figure 3D). Therefore, NPs can be arranged in the following order according to their ability to inhibit PCR Ag $>\mathrm{ZnO}>\mathrm{SiO}_{2}>\mathrm{TiO}_{2}$ (Figure 3E).

DGGE analysis of PCR reaction inhibition by NPs

Comparatively greater inhibition of PCR was observed in DGGE analysis than in agarose gel electrophoresis as shown in Figure 4A-4E. DGGE analysis of the PCR products shows that $\mathrm{TiO}_{2}$ NPs inhibit the PCR reaction by $2.8 \%$, $10.2 \%, 13.6 \%$, and $13.9 \%$ at a concentration of $0.5,1,2$, and $4 \mu \mathrm{g} / \mathrm{ml}$, 

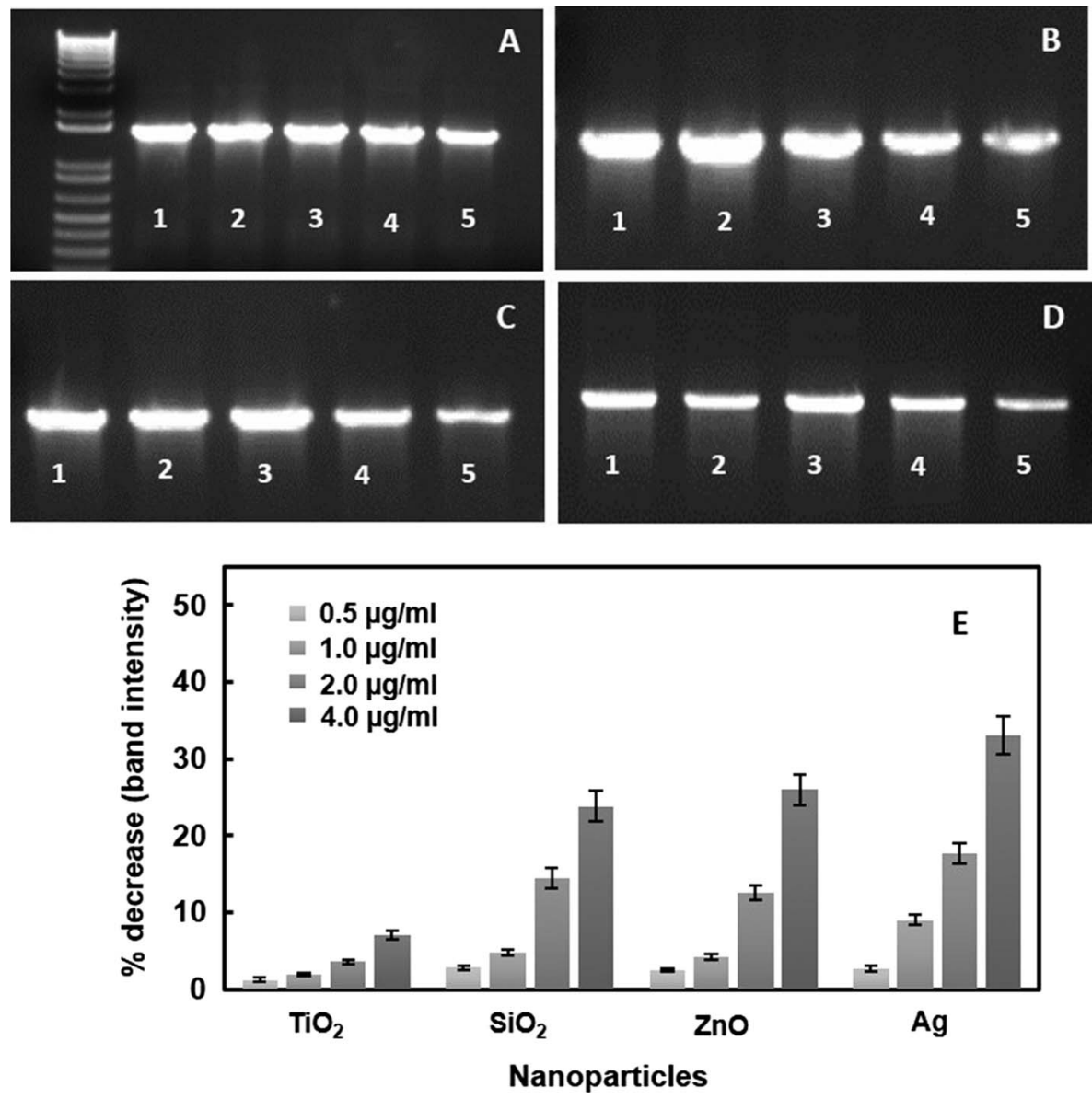

Figure 3. NPs-mediated inhibition of PCR as observed by simple agarose gel electrophoresis. A shows the PCR products obtained with $0.5,1,2$, and $4 \mu \mathrm{g} / \mathrm{ml}$ of $\mathrm{TiO}_{2}$ in lanes 2, 3, 4, and 5, respectively. $\mathrm{B}, \mathrm{C}$, and $\mathrm{D}$ show $\mathrm{PCR}$ products obtained with $\mathrm{SiO}_{2}, \mathrm{ZnO}$, and $\mathrm{Ag} \mathrm{NPs}$, respectively. In each figure, lanes $2,3,4$, and 5 show PCR products with $0.5,1,2$, and $4 \mu \mathrm{g} / \mathrm{ml}$ of NPs. E summarizes the percent decrease in the intensity of bands compared with control as measured using Gel-Quant software

respectively (Figure 4A). These values are comparatively higher than those observed in simple agarose gel electrophoresis. Similarly, an inhibition of $4.6 \%, 18.6 \%, 15.3 \%$, and $27.8 \%$ with $0.5,1,2$, and $4 \mu \mathrm{g} / \mathrm{ml}$ of $\mathrm{SiO}_{2}$, respectively, was observed (Figure 4B). Inhibitions of $2.8 \%, 20.5 \%, 35.8 \%$, and $38.2 \%$, and $7.4 \%, 37.3 \%, 37.6 \%$, and $40 \%$ with $0.5,1,2$, and $4 \mu \mathrm{g} / \mathrm{ml}$ of $\mathrm{ZnO}$ (Figure 4C) and Ag NPs (Figure 4D), respectively, were observed. It is 

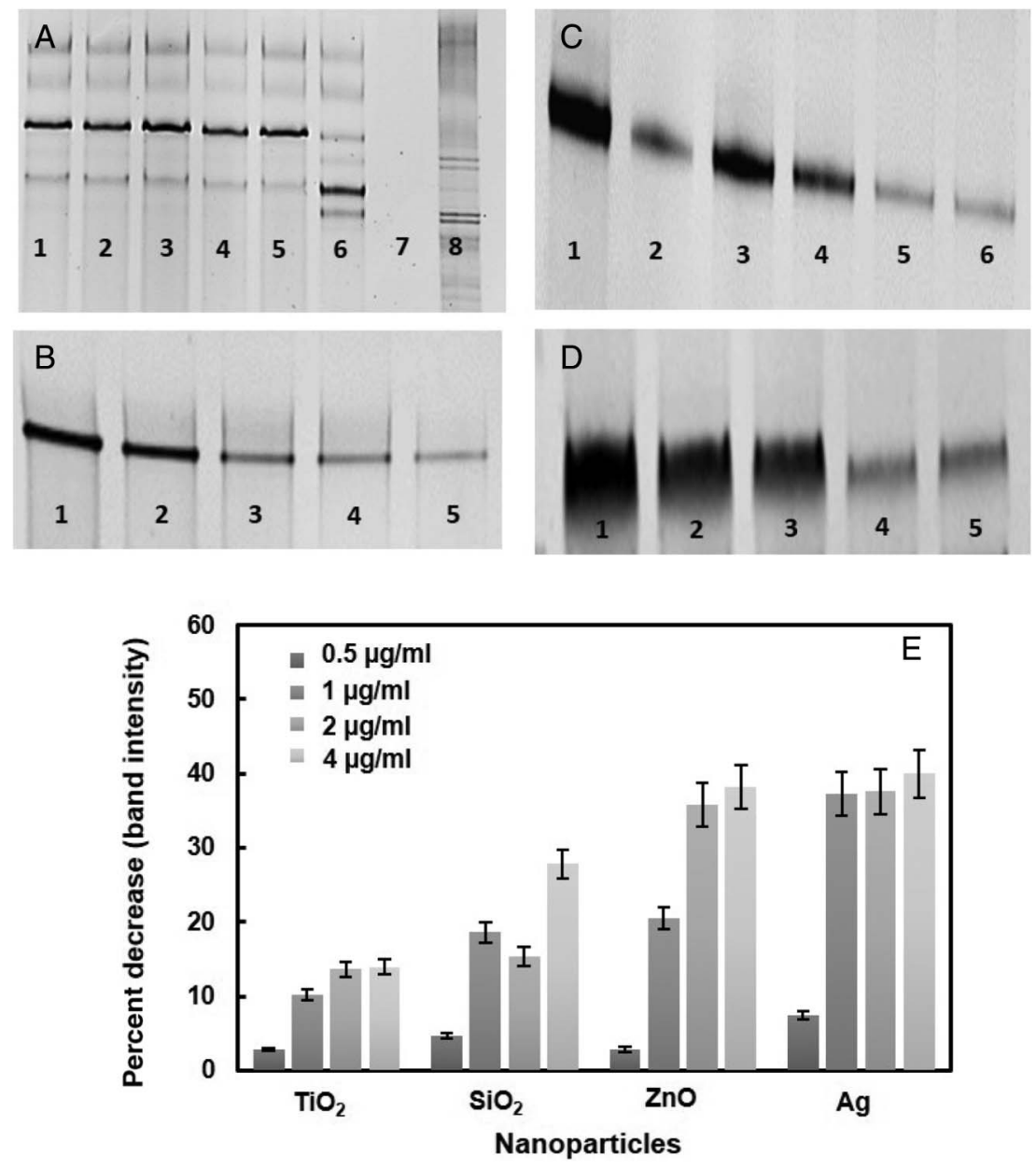

Figure 4. DGGE analysis of PCR inhibition in the presence of NPs. A shows the PCR products obtained with $0.5,1,2$, and $4 \mu \mathrm{g} / \mathrm{ml}$ of $\mathrm{TiO}_{2}$ in lanes $2,3,4$, and 5 , respectively. Lane 1 shows PCR product without any NPs, lane 6 shows PCR product from methyl methanesulfonate (MMS) treated DNA, and lane 7 is a negative control. Lane 8 shows the PCR products obtained from DNA or oral microbial community. $\mathrm{B}, \mathrm{C}$, and $\mathrm{D}$ show PCR products obtained with $\mathrm{SiO}_{2}, \mathrm{ZnO}$, and $\mathrm{Ag} \mathrm{NPs}$ respectively. In B and D, lanes 2, 3, 4, and 5 show PCR products with $0.5,1,2$, and $4 \mu \mathrm{g} / \mathrm{ml}$ of NPs. In C, lane 2 shows MMS-treated DNA while lanes $2-5$ show PCR products with $0.5,1,2$, and $4 \mu \mathrm{g} / \mathrm{ml}$ of $\mathrm{SiO}_{2}$. E summarizes the percent decrease in the intensity of DGGE bands compared with control as measured using Gel-Quant software

important to note that good separation of bands was observed for the human oral slurry sample, clearly showing that good experimental conditions were used for DGGE. Moreover, multiple bands were observed in DGGE profile of template 


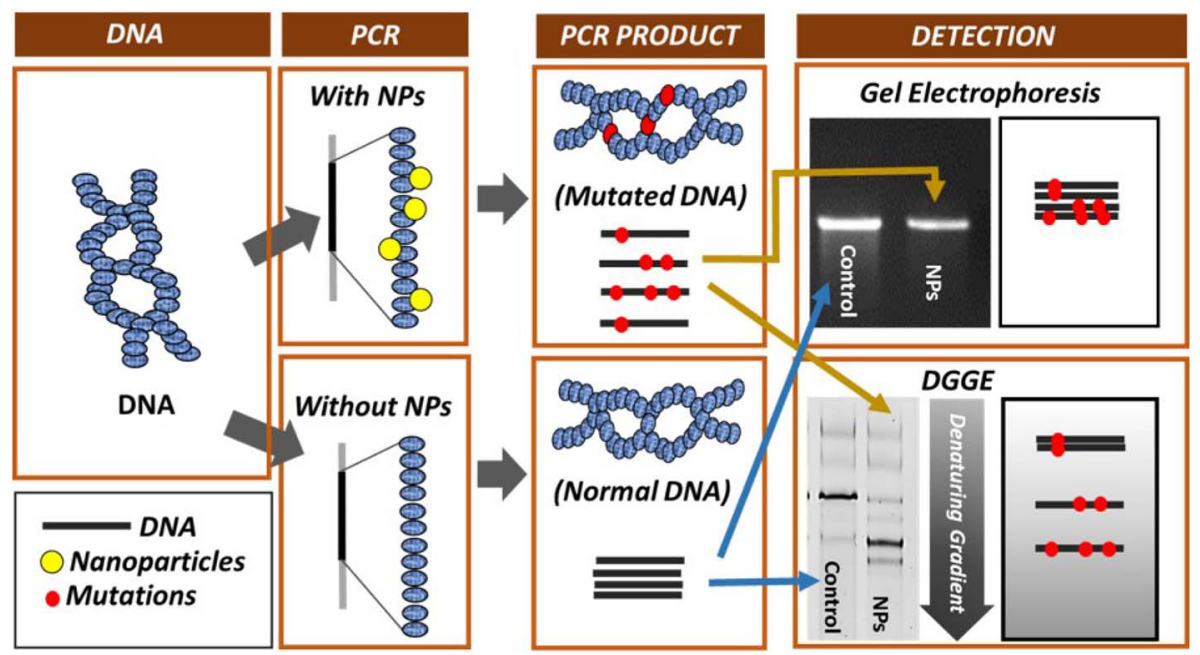

Figure 5. Schematic presentation of NPs-mediated inhibition of PCR and its subsequent detection by DGGE and gel electrophoresis

amplified from genomic DNA exposed to MMS, showing that DNA was mutated in the presence of MMS.

\section{Discussion}

As the consumption and production of NPs are ever increasing, it is important to understand the impact of these NPs on human health and the environment. Many of these NPs are known to have antimicrobial activity. Especially the antimicrobial activity of $\mathrm{Ag}$ and $\mathrm{ZnO}$ is very well known $[5,17]$. Compared with $\mathrm{Ag}$ and $\mathrm{ZnO} \mathrm{NPs}$, NPs of $\mathrm{TiO}_{2}$ exhibit milder antibacterial activity probably because $\mathrm{TiO}_{2}$ NPs exhibit the largest hydrodynamic size of $1,272 \mathrm{~nm}$, compared with other NPs tested. Even though the antimicrobial activities of NPs also depend on many other factors, such as shape and size. It is important to note that $\mathrm{SiO}_{2} \mathrm{NPs}$ exhibit higher activity against the Gram-positive bacteria than the Gram-negative bacteria. A trend that we found with $\mathrm{CuO}$ nanostructures [20]. Whether or not, and how these NPs affect microbial enzymes and biochemical processes is not understood. Urease, as discussed above, is an important enzyme from human health and environmental health point of view. Here, we report for the first time the in vitro inhibition of this enzyme by NPs; hence, these NPs can be used to treat urinary tract infections. The tested NPs 
exhibit good antimicrobial activity in addition to the inhibition of the enzymes involved in pathogenesis. $\mathrm{As}_{\mathrm{SiO}_{2}}$ is abundant in soil, the nanostructures of $\mathrm{SiO}_{2}$ can also be used in soils where the urea is lost as ammonia gas making it unavailable for plants. However, aspects of cytotoxicity and environmental hazards need thorough studies.

DNA replication and repair, a vital and complicated process, can also be inhibited by NPs through binding to DNA molecules making it unavailable for replication or by the inhibition of enzymes involved in the process. In this study, we found that the NPs inhibit the PCR, and their inhibitory activity can be arranged in the following order: $\mathrm{Ag}>\mathrm{ZnO}>\mathrm{SiO}_{2}>\mathrm{TiO}_{2}$. In a previous study, it has been argued that the potential of NPs to inhibit PCR depends on their affinity to bind to DNA molecules [11]. On the contrary, it was also reported that even though $\mathrm{TiO}_{2}$ NPs bind to DNA, they do not inhibit the reaction. In our studies, the least inhibitory $\mathrm{NPs}_{\text {sere }} \mathrm{TiO}_{2}$ and this possibly can be due to the largest hydrodynamic size of $\mathrm{TiO}_{2}$ NPs as observed by DLS analysis. Other NPs exhibit comparable hydrodynamic sizes and can be arranged in the following order according to their hydrodynamic sizes: $\mathrm{TiO}_{2}>\mathrm{SiO}_{2}>$ $\mathrm{ZnO}>\mathrm{Ag}$ (Table I). The release of metal ions from NPs also plays an important role in their biocidal activity. The release of $\mathrm{Zn}^{2+}$ ions from $\mathrm{ZnO}$ NPs has been reported by Song et al. [21]. Weakly charged Au NPs-mediated DNA bending and strand separation has also been reported [13]. Moreover, $\mathrm{SiO}_{2}, \mathrm{TiO}_{2}$, and $\mathrm{ZnO}$ NPs-mediated DNA damage in in vivo study is also reported in earlier studies [22-24].

It is also important to note that a higher inhibition of PCR was observed during DGGE analysis than in agarose gel electrophoresis. This may be due to the migration of mutated DNA fragments at positions different from the original band as in DGGE analysis fragments of different sequence but of the same size migrate differently (Figure 5). The mutagenic potential of metal and metal oxide NPs including $\mathrm{Ag}, \mathrm{TiO}_{2}$, and $\mathrm{ZnO}$ NPs using Ames testing is reported earlier $[25,26]$. However, in our DGGE analysis except for Ag NPs, multiple bands were not observed in the gel. This may be due to the low copy numbers of mutated DNA, which were not in detectable range in DGGE gels. However, proper separation of bands differing in the sequence obtained from a mixed bacterial population was observed as shown in Figure 3A, lane 8. Previous studies have reported the mutagenic potential of NPs using methods like Ames testing [25, 26], comet assay, and DNA sequencing [27]. But these techniques are expensive and time taking. Results presented in this study strongly suggests that DGGE can be a sensitive, quick, and inexpensive technique to study the PCR inhibition potential of the NPs. 


\section{Conclusion}

Results presented in this study clearly show that the tested NPs inhibit the microbial growth and the activities of urease and DNA polymerase enzymes. $\mathrm{TiO}_{2}$ was found to be the least inhibitory while Ag NPs inhibited significantly microbial growth and the enzyme activity. DGGE can serve as a sensitive, quick, and inexpensive technique for checking the qualitative and quantitative inhibition of DNA polymerase.

\section{Acknowledgement}

This study was financially supported by the King Saud University, Vice Deanship of Research Chairs.

\section{Conflict of Interest}

The authors declare no conflict of interest.

\section{References}

1. Piccinno, F., Gottschalk, F., Seeger, S., Nowack, B.: Industrial production quantities and uses of ten engineered nanomaterials in Europe and the world. J Nanoparticle Res 14, 1-11 (2012).

2. Abeylath, S. C., Turos, E.: Drug delivery approaches to overcome bacterial resistance to beta-lactam antibiotics. Expert Opin Drug Deliv 5, 931-949 (2008).

3. Espitia, P. J. P., Soares, N. D. F. F., dos Reis Coimbra, J. S., de Andrade, N. J., Cruz, R. S., Medeiros, E. A. A.: Zinc oxide nanoparticles: Synthesis, antimicrobial activity and food packaging applications. Food Bioprocess Technol 5, 1447-1464 (2012).

4. Weir, A., Westerhoff, P., Fabricius, L., Hristovski, K., von Goetz, N.: Titanium dioxide nanoparticles in food and personal care products. Environ Sci Technol 46, 2242-2250 (2012).

5. Khan, S. T., Al-Khedhairy, A. A., Musarrat, J.: $\mathrm{ZnO}$ and $\mathrm{TiO}_{2}$ nanoparticles as novel antimicrobial agents for oral hygiene: A review. J Nanoparticle Res 17, 1-16 (2015).

6. Khan, S. T., Ahamed, M., Al-Khedhairy, A., Musarrat, J.: Biocidal effect of copper and zinc oxide nanoparticles on human oral microbiome and biofilm formation. Mater Lett 97, 67-70 (2013).

7. Rai, M., Deshmukh, S., Ingle, A., Gade, A.: Silver nanoparticles: The powerful nanoweapon against multidrug-resistant bacteria. J Appl Microbiol 112, 841-852 (2012).

8. Khan, S. T., Musarrat, J., Al-Khedhairy, A. A.: Countering drug resistance, infectious diseases, and sepsis using metal and metal oxides nanoparticles: Current status. Colloids Surf B Biointerfaces 146, 70-83 (2016). 
9. Rutherford, J. C.: The emerging role of urease as a general microbial virulence factor. PLoS Pathogens 10, e1004062 (2014).

10. Dai, X. R., Karring, H.: A determination and comparison of urease activity in feces and fresh manure from pig and cattle in relation to ammonia production and $\mathrm{pH}$ changes. PLoS One 9, e110402 (2014).

11. Li, K., Zhao, X., Hammer, B. K., Du, S., Chen, Y.: Nanoparticles inhibit DNA replication by binding to DNA: Modeling and experimental validation. ACS Nano 7, 9664-9674 (2013).

12. Paillusson, F., Dahirel, V., Jardat, M., Victor, J.-M., Barbi, M.: Effective interaction between charged nanoparticles and DNA. Phys Chem Chem Phys 13, 12603-12613 (2011).

13. Railsback, J. G., Singh, A., Pearce, R. C., McKnight, T. E., Collazo, R., Sitar, Z., Yingling, Y. G., Melechko, A. V.: Weakly charged cationic nanoparticles induce DNA bending and strand separation. Adv Mater 24, 4261-4265 (2012).

14. Nandanwar, R., Singh, P., Haque, F. Z., Shabanda, I., Kabiru, N., Bolognesi, L. F. C., Borges, F. A., Cinman, J. L. F., da Silva, R. G., dos Santos, A. G.: Synthesis and characterization of $\mathrm{SiO}_{2}$ nanoparticles by sol-gel process and its degradation of methylene blue. Am Chem Sci J 5, 1-10 (2015).

15. Raja, M., Shanmugaraj, A. M., Ryu, S. H.: Preparation of template free zinc oxide nanoparticles using sol-gel chemistry. J Nanosci Nanotechnol 8, 4224-4226 (2008).

16. Castro, A., Nunes, M., Carvalho, A., Costa, F., Florencio, M.: Synthesis of anatase $\mathrm{TiO}_{2}$ nanoparticles with high temperature stability and photocatalytic activity. Solid State Sci 10, 602-606 (2008).

17. Khan, M., Khan, S. T., Adil, S. F., Musarrat, J., Al-Khedhairy, A. A., Al-Warthan, A., Siddiqui, M. R., Alkhathlan, H. Z.: Antibacterial properties of silver nanoparticles synthesized using Pulicaria glutinosa plant extract as a green bioreductant. Int J Nanomed 9, 3551-3565 (2014).

18. Khan, S. T., Nakagawa, Y., Harayama, S.: Galbibacter mesophilus gen. nov., sp. nov., a novel member of the family Flavobacteriaceae. Int J Syst Bacteriol 57, 969-973 (2007).

19. Lundin, C., North, M., Erixon, K., Walters, K., Jenssen, D., Goldman, A. S., Helleday, T.: Methyl methanesulfonate (MMS) produces heat-labile DNA damage but no detectable in vivo DNA double-strand breaks. Nucleic Acids Res 33, 3799-3811 (2005).

20. Wahab, R., Khan, S. T., Dwivedi, S., Ahamed, M., Musarrat, J., Al-Khedhairy, A. A.: Effective inhibition of bacterial respiration and growth by $\mathrm{CuO}$ microspheres composed of thin nanosheets. Colloids Surf B Biointerfaces 111, 211-217 (2013).

21. Song, W., Zhang, J., Guo, J., Ding, F., Li, L., Sun, Z.: Role of the dissolved zinc ion and reactive oxygen species in cytotoxicity of $\mathrm{ZnO}$ nanoparticles. Toxicol Lett 199, 389-397 (2010).

22. Trouiller, B., Reliene, R., Westbrook, A., Solaimani, P., Schiestl, R. H.: Titanium dioxide nanoparticles induce DNA damage and genetic instability in vivo in mice. Cancer Res 69, 8784-8789 (2009).

23. Kang, T., Guan, R., Chen, X., Song, Y., Jiang, H., Zhao, J.: In vitro toxicity of different-sized $\mathrm{ZnO}$ nanoparticles in Caco-2 cells. Nanoscale Res Lett 8, 1-8 (2013).

24. Duan, J., Yu, Y., Li, Y., Yu, Y., Li, Y., Zhou, X., Huang, P., Sun, Z.: Toxic effect of silica nanoparticles on endothelial cells through DNA damage response via Chk1-dependent G2/M checkpoint. PLoS One 8, e62087 (2013). 
25. Kim, H. R., Park, Y. J., Da Young Shin, S. M. O., Chung, K. H.: Appropriate in vitro methods for genotoxicity testing of silver nanoparticles. Environ Health Toxicol 28, e2013003 (2013).

26. Pan, X., Redding, J. E., Wiley, P. A., Wen, L., McConnell, J. S., Zhang, B.: Mutagenicity evaluation of metal oxide nanoparticles by the bacterial reverse mutation assay. Chemosphere 79, 113-116 (2010).

27. Ahmad, J., Dwivedi, S., Alarifi, S., Al-Khedhairy, A. A., Musarrat, J.: Use of $\beta$-galactosidase (lacZ) gene $\alpha$-complementation as a novel approach for assessment of titanium oxide nanoparticles induced mutagenesis. Mutat Res 747, 246-252 (2012). 